A further realm in which Wills made major contributions was in the Pleistocene history of the Midlands, with its story of advance and retreat of continental glaciers, recognising the evidence of extensive icedammed lakes of which one, which he named Lake Lapworth, covered much of the northwest Midlands. This was classic work which has served as the basis for all subsequent studies of Midlands glaciation and river development.

Wills' long term interest in the Palaeozoic rocks of Wales, in the contrasting regimes represented by the Midlands Trias blanketing concealed coalfields, in the marine later Mesozoic and in the complex deposits of the glacial period led to a series of books in which environmental aspects are a major theme. The first was his Physiographical Evolution of Great Britain (1929), later came The Palaeogeography of the Midlands (1948), A Palaeogeographical Atlas of the British Isles (1951), and Concealed Coalfields (1956).

Of these publications, the Palaeogeographical Atlas has been widely used by industry as well as by academics, being particularly valuable to the petroleum industry when North Sea exploration led to the requirement for broad regional appraisals. This made "Wills" a household name for petroleum geologists. It was a notable production, including 49 maps of Britain and the adjoining areas from the Lower Palaeozoic to the Quaternary, covering tectonics, palaeogeography, sedimentary facies and glaciation. Authorities are listed for each map - often ten or eleven individuals as well as the Geological Survey - demonstrating the thoroughness of the compilation. Many of the sources provided previously unpublished information, for example from the deep boreholes made in the course of onshore exploration for oil in the 1930s and 1940s.

Wills retired from the Chair of Geology in 1949 , but his thirty years in retirement were highly productive. After the work on the anatomy of fossil arthropods and publication of his text books he continued to work on problems of the Midlands Trias and to compile data on the deep geology of England and Wales. Increasing infirmity confined him to his country home near Romsley, but he was an indefatigable correspondent and kept in touch with a range of friends who could provide a flow of new information for analysis and compilation. At the age of 89 , in 1973 , he completed and published a palaeogeological map of the buried pre-Permian formations of England and Wales, a map which found an immediate place on the walls of many offices and most geological departments in the country.

It was assumed that in the face of physical frailty, with only one eye useable and a serious heart condition, this would be his last production, but two years later he followed this masterpiece with a palaeo- geological map at a deeper level - the surface of the strata with Upper Devonian and later formations removed, and this led in turn to a third map of pre-Devonian formations. Each map of this series threw new light on the deep structure and stratigraphic relations of deeply buried rocks. The last two were published together with a memoir on the data and on their interpretation in 1978, and with them his scientific work finally came to an end.

Wills had been honoured by the Geological Society by the award of the Lyell Medal (1936) and the Wollaston Medal (1954) - its highest award. In recognition of his continuing prowess he was made the only British Honorary Fellow at the age of 92. The Petroleum Exploration Society elected him a life member and helped to finance his maps, and in his last few years he received medals also from the Yorkshire Geological Society and from Birmingham University.

As a lecturer Wills was difficult to follow but inspired a generation of students with his enthusiasm and interest. In his retirement he could not have accomplished so much without the support of his old university, of a wide range of correspondents, and the devotion of his daughter who looked after him for nearly thirty years after the loss of his wife. But he attracted universal affection and cooperation, and his friends felt it a pleasure and honour to be able to help him in his continuing scientific achievement.

Peter Kent

\section{John W. Mauchly}

THE DEATH occurred on 8 January 1980 at the age of 72 of John W. Mauchly who, with Dr J. P. Eckert, conceived and carried through the project for the development of the first large-scale electronic computer. This was the ENIAC (Electronic Numerical Integrator and Computer), built at the Moore School of Electrical Engineering in Philadelphia during the latter part of the war.

Mauchly was born in Cincinnati in 1907 and grew up in Chevy Chase, Maryland. After taking his $\mathrm{PhD}$ at Johns Hopkins University, he went to Ursinus College as head of the physics department. During several summers he worked at the department of terrestrial magnetism of the Carnegie Institution in Washington DC, where his father was employed as a physicist. In this way, Mauchly acquired an interest in weather problems that he retained throughout his life. It was while he was working on a project for the analysis of weather records that he began to appreciate the pressing need for some automatic means of computation. He early realised the role that electronics might play and he began to do some experiments in his spare time.

In 1941 Mauchly joined the faculty of the University of Pennsylvania at the Moore School and there he met J. P. Eckert. Together, in 1942, they wrote the proposal for the ENIAC. They were able to interest the US Ordnance Department - which was facing an unprecedented wartime demand for the computation of ballistic tables - in the proposal, and as a result substantial funds were made available. The ENIAC was running by the summer of 1945 and was formally dedicated on 15 February 1946.

The ENIAC contained nearly 19,000 vacuum tubes and its construction represented an outstanding example of technological courage, both on the part of its young designers and on the part of those who gave them support. Its completion was an important landmark in the development of digital computers; however, even more significant in the long term was the formulation, by Mauchly and Eckert, in association with the ENIAC group, of the principles on which modern stored program computers are constructed.

Towards the end of 1946 Mauchly left the Moore School to found, with Eckert, the Eckert-Mauchly Corporation, intended to exploit the new ideas. All went well, although the development of a stored program computer to meet commercial standards was proving a long drawn-out process, until 1950, when they suffered a severe blow by the loss of their sponsor in an air accident. This led directly to the Eckert-Mauchly Corporation being absorbed in Remington-Rand, but happily the name UNIVAC, which they gave to their computer, has survived.

Mauchly remained with RemingtonRand, which in due course, became merged with the Sperry Corporation, until 1959, when he formed a consulting company of his own. In his later years he became associated once more, on a consulting basis, with UNIVAC.

Mauchly was a member of the National Academy of Engineering and a Fellow of the IEEE. He was one of the founders of the Association for Computing Machinery and was its President during the years 1948-50. In 1966 he received the Harry Goode Memorial Award of the American Federation of Information Processing Societies. In addition, he received numerous other honours and awards.

Mauchly was twice married. His first wife, Mary, whom he married in 1930, was drowned in a tragic bathing accident in September 1946. In February 1948 he married Kay McNulty, who had worked as a programmer on the ENIAC. She survives him, along with two sons and five daughters. Mauchly was a man of great personal charm, with a gentle approach to people and affairs. His many friends will miss him greatly.

M. V. Wilkes 